\title{
Działalność Mazowieckiego Biura Planowania Regionalnego na rzecz rozwoju województwa mazowieckiego - efekty w subregionie siedleckim
}

\section{Urszula Gadomska}

STRESZCZENIE

Artykuł przedstawia wybrane zadania Mazowieckiego Biura Planowania Regionalnego (MBPR), których realizacja miała znaczący wpływ na rozwój subregionu siedleckiego.

Biuro od 20 lat realizuje obowiązki samorządu Województwa Mazowieckiego w zakresie polityki rozwoju i zagospodarowania przestrzennego. Opracowywane w Biurze, szeroko uspołeczniane dokumenty strategiczne i opracowania analityczno-studialne, pozwoliły na jak najlepsze uwzględnienie specyfiki poszczególnych obszarów Mazowsza w polityce rozwoju regionu, prowadzonej przez jego władze. Władze, a efektami na obszarach słabo rozwiniętych, w tym w subregionie siedleckim, były m.in. preferencje w dofinansowywaniu projektów ze środków Unii Europejskiej (UE) w ramach kolejnych edycji Regionalnego Programu Operacyjnego Województwa Mazowieckiego (RPOWM).

Bardzo ważnym aspektem polityki rozwoju regionu jest także wspieranie współpracy samorządów różnych poziomów w realizacji zadań o znaczeniu ponadlokalnym. W ostatnich latach, w wyniku współdziałania jednostek samorządu województwa, w tym MBPR, z samorządami lokalnymi, powstały zintegrowane plany inwestycyjne w poszczególnych obszarach Mazowsza, m.in. w subregionie siedleckim. Ich realizacja przebiega przy dofinansowaniu z RPOWM 2014-2020 w ramach specjalnego instrumentu wsparcia pod nazwą Regionalne Inwestycje Terytorialne.

Słowa kluczowe: polityka rozwoju regionu, samorząd województwa mazowieckiego, Siedlce, subregion siedlecki

\section{Wstęp}

Na wstępie pragnę podkreślić, że niniejszy artykuł nie jest kompleksowym opisem działalności Mazowieckiego Biura Planowania Regionalnego (MBPR), lecz przedstawia wybrane $\mathrm{z}$ ogromnego dorobku tej instytucji zadania, w których jako pracownik Oddziału Terenowego MBPR w Siedlcach brałam udział, i które subiektywnie uznałam za reprezentatywne do podkreślenia roli, jaką Biuro odgrywa w prowadzeniu polityki rozwoju województwa mazowieckiego. W związku z tym, że mieszkam i pracuję w Siedlcach, moje spojrzenie $z$ tej perspektywy na działalność MBPR, a szczególnie jej efekty w subregionie siedleckim - jednym z najsłabiej rozwiniętych obszarów Mazowsza, może znacząco różnić się od spojrzenia z Warszawy lub innej części województwa.

Załoga naszego oddziału stała się pracownikami ówczesnego Mazowieckiego Biura Planowania Przestrzennego i Rozwoju Regionalnego (MBPPiRR) w 1999 r. (nazwa Mazowieckie Biuro Planowania Regionalnego używana jest od 2006 r.). Po reformie administracyjnej Polski, ustanawiającej 16 samorządowych województw, likwidowane Wojewódzkie Biuro Planowania Przestrzennego w Siedlcach, w którym pracowaliśmy, 
zostało włączone w struktury nowo powstałego MBPPiRR jako jego Oddział Terenowy (analogicznie jak Biura w: Radomiu, Płocku, Ostrołęce i Ciechanowie).

Nowa jednostka została powołana do realizacji zadań samorządu województwa mazowieckiego w zakresie polityki rozwoju i zagospodarowania przestrzennego, dlatego na przestrzeni 20 lat jej funkcjonowania główne zadania dotyczyły: sporządzania, monitorowania i aktualizowania strategii rozwoju oraz planu zagospodarowania przestrzennego regionu, a także wykonywania prac analityczno-studialnych dla wybranych problemów i obszarów Mazowsza. Od 2007 r. Biuro ponadto przygotowuje w imieniu samorządu województwa uzgodnienia i opinie do projektów różnego rodzaju dokumentów, w tym z zakresu planowania przestrzennego i energetycznego, prowadzonego przez gminy i przedsiębiorstwa energetyczne (opinie w zakresie energetyki należą do wyłącznej właściwości Oddziału w Siedlcach).

Ww. reforma, wprowadzająca od 1 stycznia 1999 r. nowy podział administracyjny kraju, wywołała w mieszkańcach Siedlec mieszane uczucia: z jednej strony nasze miasto traciło rangę dobrze rozwijającej się stolicy województwa siedleckiego, funkcjonującego od 1975 r., z drugiej - subregion siedlecki został częścią największego w Polsce województwa mazowieckiego ze stolicą $w$ Warszawie. Teraz ta metropolia stała się dla nas znacznie bardziej dostępna - była siedzibą wielu instytucji działających na naszym terenie, a wizja rozwoju regionu brzmiała: „Warszawa ku Europie, Mazowsze z Warszawa”․․․ Jednym z głównych celów rozwojowych stało się zmniejszenie wewnętrznego zróżnicowania i zwiększenie spójności regionu. My, pracownicy samorządowi nowego województwa, musieliśmy nauczyć się myśleć o subregionie siedleckim, jako części tego dużego organizmu, którego rozwój zaczynaliśmy planować, mając na uwadze ogromne dysproporcje pomiędzy częścią centralną a dużo gorzej rozwiniętymi obszarami peryferyjnymi. Polityka rozwoju województwa, formułowana i realizowana przez jego samorządowe władze, od początku zakładała wykorzystanie potencjału gospodarczego, kulturowego i intelektualnego miast subregionalnych: Radomia, Płocka, Siedlec, Ostrołęki i Ciechanowa².

\section{Strategia rozwoju i plan zagospodarowania przestrzennego województwa}

Oddział Terenowy MBPR w Siedlcach już od początku działalności Biura uczestniczył w pracach nad pierwszą Strategia rozwoju województwa mazowieckiego (SRWM), uchwaloną w 2001 r. (zaktualizowaną w 2006 r. - po wejściu Polski do Unii Europejskiej), a później Planem zagospodarowania przestrzennego województwa mazowieckiego (PZPWM), przyjętym w $2004 \mathrm{r}$. Prace nad ww. pierwszym Planem były koordynowane w naszym Oddziale ${ }^{3}$. Pracownicy Oddziału siedleckiego brali także udział w opracowaniu Studium planu zagospodarowania przestrzennego Obszaru Metropolitalnego Warszawy.

\footnotetext{
${ }^{1}$ Wizja przedstawiona w pierwszej Strategii rozwoju województwa mazowieckiego.

${ }^{2}$ Zgodnie z zapisami pierwszej Strategii rozwoju województwa mazowieckiego.

${ }^{3}$ Głównym projektantem pierwszego Planu zagospodarowania przestrzennego województwa mazowieckiego był dr Stefan Białczak (dyrektor Oddziału Terenowego MBPR w Siedlcach w latach 2005-2007).
} 
Należy podkreślić, że w ww. dokumentach znaczna cześć subregionu siedleckiego (obszar nadbużański) - ze względu na zidentyfikowane problemy rozwojowe - została uznana za obszar problemowy, wymagający aktywnej polityki regionalnej. Skutkowało to $\mathrm{m}$.in. preferencjami punktowymi w ocenie strategicznej projektów z przedmiotowego obszaru, aplikujących o dofinansowanie z Regionalnego Programu Operacyjnego Województwa Mazowieckiego 2007-2013 (RPOWM 2007-2013), którą przeprowadzali pracownicy MBPR, powołani na ekspertów w tej dziedzinie.

W latach 2011-2014 opracowane zostały kolejne edycje SRWM i PZPWM, które poddano szerokiej partycypacji społecznej. Aktualizacja tych dokumentów była przedmiotem cyklu konferencji informacyjno-konsultacyjnych, organizowanych przez MBPR, m.in. w Siedlcach. Większości z nich przewodniczyli przedstawiciele Zarządu Województwa Mazowieckiego. Szczególnie wysoką rangę miała konferencja, która odbyła się w listopadzie 2011 r. w Pałacu Ogińskich $^{4}$ - siedzibie władz Uniwersytetu Przyrodniczo-Humanistycznego w Siedlcach (UPH) (fot. 1). Po przedstawieniu założeń aktualizacji dokumentów strategicznych województwa mazowieckiego, odbyła się dyskusja na temat perspektyw rozwojowych subregionu siedleckiego. W panelu dyskusyjnym wzięli udział przedstawiciele: parlamentu, rządu, lokalnych władz samorządowych, środowiska naukowego i biznesu ${ }^{5}$.

Najważniejsze wypowiedzi panelistów dotyczyły:

- usprawnienia powiązań komunikacyjnych - zarówno zewnętrznych, jak i wewnętrznych w województwie, szczególnie konieczność realizacji dróg szybkiego ruchu i szybkich kolei;

- zwiększenia efektywności energetycznej oraz skojarzonej produkcji energii elektrycznej i cieplnej, a także wykorzystania odnawialnych źródeł energii (poprzez uproszczenie przepisów w tym zakresie);

- nowoczesnej gospodarki odpadami;

- wspomagania rozwoju przemysłu, w tym przemysłu metalowego i spożywczego w subregionie siedleckim;

- efektywnego wykorzystania potencjału rolniczego, w tym zwiększenia produkcji surowców dla przemysłu rolno-spożywczego poprzez odpowiednie zachęty finansowe ze środków UE;

- $\quad$ wspomagania rozwoju szkół wyższych, m.in. ich specjalistycznego wyposażenia;

- efektywniejszego wykorzystania środków przeznaczonych na ochronę zdrowia, przede wszystkim rozwój specjalistycznych szpitali wojewódzkich;

- wykorzystania potencjału przyrodniczo-kulturowego, rozwoju infrastruktury turystycznej.

\footnotetext{
${ }^{4}$ Konferencji przewodniczyła Pani Janina Ewa Orzełowska - członek Zarządu Województwa Mazowieckiego.

${ }^{5}$ Dyskusję poprowadził dr Jan Borkowski - Sekretarz Stanu w Ministerstwie Spraw Zagranicznych (wcześniej m.in. Wicewojewoda Siedlecki i Poseł na Sejm RP), a udział wzięli: Krzysztof Borkowski - Poseł na Sejm RP, Wojciech Kudelski - Prezydent Miasta Siedlce, Zygmunt Wielogórski - Starosta Powiatu Siedleckiego, prof. dr hab. Antoni Jówko - Rektor Uniwersytetu Przyrodniczo-Humanistycznego w Siedlcach, Aleksander Jonek - Przewodniczący Siedleckiej Rady Biznesu.
} 
Wnioski z ww. dyskusji zostały uwzględnione w zaktualizowanych dokumentach strategicznych województwa mazowieckiego, m.in. w zapisach odnoszących się bezpośrednio do subregionu siedleckiego, uznanego w całości za problemowy obszar strategicznej interwencji (OSI), wymagający wsparcia z poziomu krajowego i regionalnego. Taki status subregionu umożliwił późniejsze dofinansowanie zintegrowanych inwestycji w jego obszarze z Regionalnego Programu Operacyjnego Wojezództwa Mazowieckiego na lata 2014-2020 (RPOWM 2014-2020), na preferencyjnych warunkach w ramach Regionalnych Inwestycji Terytorialnych - instrumentu omówionego w dalszej części artykułu.

Najnowsza aktualizacja PZPWM z 2018 r. także wykorzystała wyniki przeprowadzonych konsultacji społecznych, m.in. podczas konferencji, która odbyła się w czerwcu 2018 r. w Siedlcach ${ }^{6}$ (fot. 2). Tematem spotkania było podsumowanie realizacji dotychczasowej

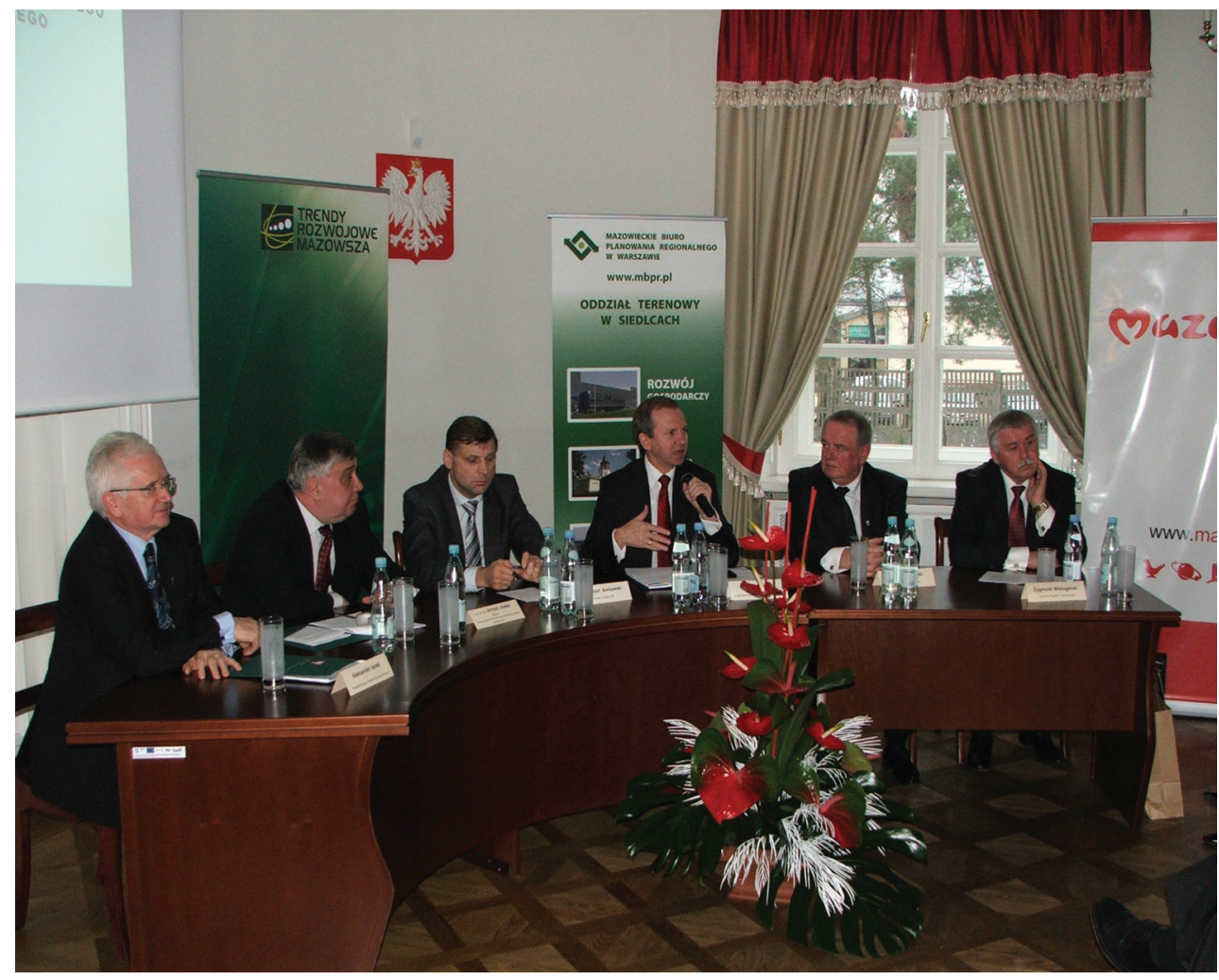

Fot. 1. Dyskusja nt. perspektyw rozwojowych subregionu siedleckiego na konferencji, Uniwersytet Przyrodniczo-Humanistyczny w Siedlacach, 30 listopada 2011 r. Źródło: materiały archiwalne MBPR

\footnotetext{
${ }^{6}$ Konferencji przewodniczył Pan Adam Struzik - Marszałek Województwa Mazowieckiego.
} 


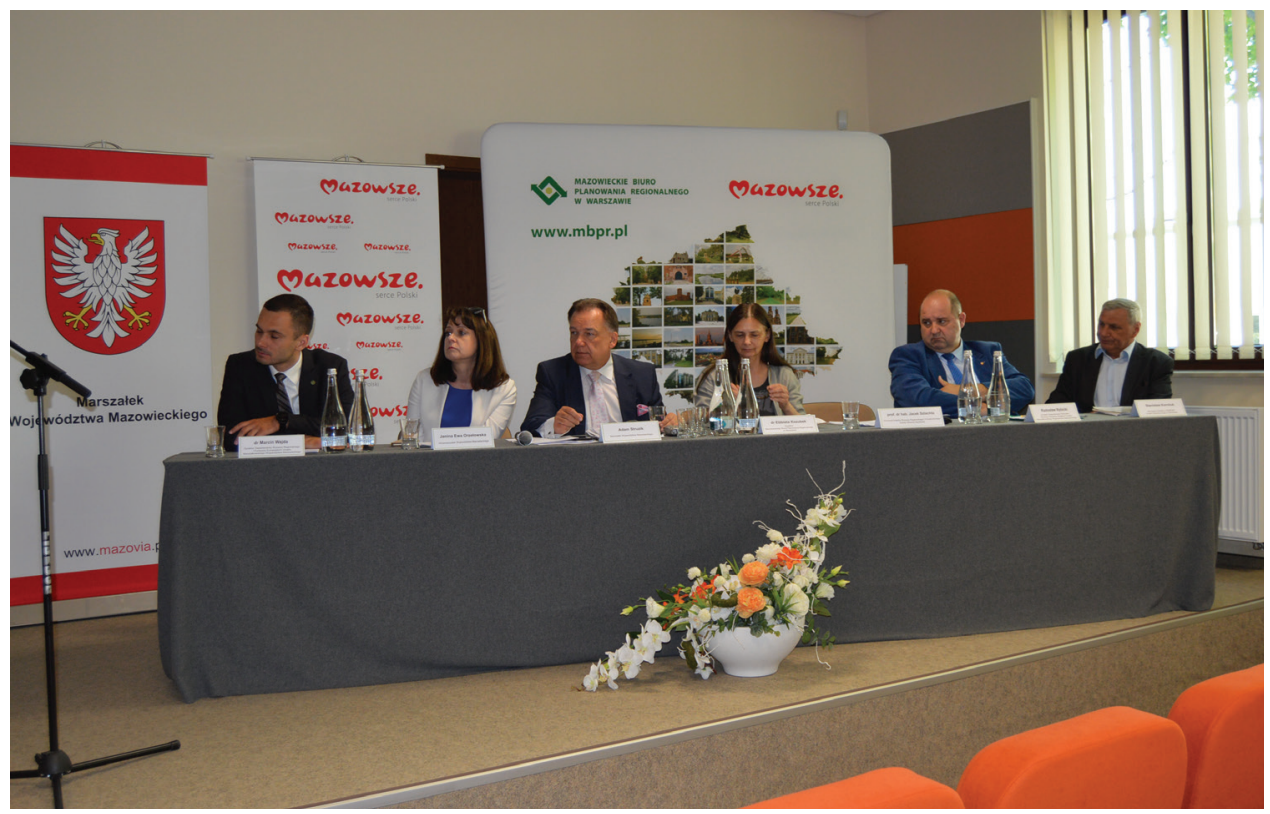

Fot. 2. Konferencja nt. przyszłości województwa mazowieckiego

Mazowieckie Samorządowe Centrum Doskonalenia Nauczycieli w Siedlcach, 4 czerwca 2018 r. Źródło: materiały archiwalne MBPR

polityki rozwoju województwa oraz debata o przyszłości Mazowsza w kontekście zmiany PZPWM, nowego podziału statystycznego regionu i funduszy pomocowych UE w perspektywie finansowej po 2020 r. Podczas debaty, w której wzięli udział przedstawiciele samorządów lokalnych, podkreślono przyszłe potrzeby rozwojowe subregionu siedleckiego, zwłaszcza z zakresu infrastruktury transportowej.

\section{Analizy i studia}

W całym okresie działalności MBPR, Oddział Terenowy w Siedlcach wykonywał opracowania analityczno-studialne na potrzeby prowadzenia polityki rozwoju województwa oraz monitoringu i aktualizacji dokumentów strategicznych i programowych. Większość tego typu opracowań zostało sporządzonych we współpracy z samorządami lokalnymi i organizacjami pozarządowymi, kilka przy udziale środowiska akademickiego. Problematyka opracowań była przedmiotem referatów przedstawianych przez pracowników Oddziału na różnego rodzaju spotkaniach i konferencjach ( $\mathrm{w}$ tym konferencjach naukowych na temat turystyki ${ }^{7}$ oraz

\footnotetext{
${ }^{7}$ M.in. referaty Barbary Dymnej, Urszuli Gadomskiej, Andrzeja Dombrowskiego i Anny Olszewskiej na międzynarodowych konferencjach naukowych, organizowanych w latach 2006-2008 przez: Zakład Turystyki Zamiejscowego Wydziału Wychowania Fizycznego w Białej Podlaskiej (obecnie Filia Akademii Wychowania Fizycznego w Warszawie), Akademię Podlaską w Siedlcach (obecnie Uniwersytet Przyrodniczo-Humanistyczny) oraz Uniwersytet Marii Curie-Skłodowskiej w Lublinie.
} 
forach branżowych z zakresu energetyki ${ }^{8}$, a także Festiwalu Nauki i Sztuki ${ }^{9}$, organizowanym przez UPH).

Do najważniejszych opracowań analityczno-studialnych, wykonanych w Oddziale, należą:

- założenia do programu działań w obszarze nadbużańskim - opracowanie dotyczące jednego z obszarów problemowych, wyznaczonych w SRWMi PZPWM, wykonane we współpracy z Delegaturą Urzędu Marszałkowskiego Województwa Mazowieckiego w Siedlcach, mające na celu zdiagnozowanie potrzeb inwestycyjnych, wymagających dofinansowania ze środków publicznych, w tym szczególnie środków UE w ramach RPOWM 2007-2013;

- opracowania z zakresu turystyki - koncepcje szlaków turystyczno-kulturowych w pasmach rzek: Wilgi, Bugu i Liwca; koncepcje sieciowych produktów turystycznych w subregionie siedleckim; analiza działalności gmin na rzecz rozwoju turystyki;

- opracowania z zakresu energetyki na temat: planowania i organizacji zaopatrzenia w energię w gminach; rozwoju energetyki opartej na źródłach odnawialnych; planowanych sieci przesyłowych;

- analiza możliwości wykorzystania potencjału Uniwersytetu PrzyrodniczoHumanistycznego dla wzrostu konkurencyjności Siedlec - wykonana w związku z bardzo aktywnym udziałem siedleckich władz samorządowych i UPH w procesie aktualizacji SRWM i PZPWM; złożone przez ww. podmioty wnioski merytoryczne powiązano w spójne koncepcje działań, służących podniesieniu konkurencyjności Siedlec;

- koncepcja zagospodarowania przestrzennego miejskiego obszaru funkcjonalnego Siedlec.

Dwa ostatnie z ww. opracowań, były przedmiotem ważnych i efektywnych dyskusji, zorganizowanych przez siedlecki oddział MBPR, w których wzięl iudział m.in. przedstawiciele lokalnych władz.

Debata, która odbyła się w czerwcu 2014 r. w siedzibie UPH (fot. 3), miała na celu upowszechnienie treści zawartych $\mathrm{w}$ ww. opracowaniu analityczno-studialnym MBPR, opublikowanym pod tytułem: Możliwości wykorzystania potencjału Uniwersytetu PrzyrodniczoHumanistycznego dla wzrostu konkurencyjności miejskiego obszaru funkcjonalnego Siedlec. W opracowaniu wykazano, że działalność Uniwersytetu może istotnie wzmocnić efekty działań inwestycyjnych i organizacyjnych, planowanych przez lokalne władze samorządowe na obszarze miasta i gminy Siedlce w latach 2014-2020, a także przedstawiono koncepcje wspólnych działań, mających na celu rozwój następujących funkcji Siedlec: transportowologistycznych, gospodarczych, energetycznych, rekreacyjno-turystycznych, kulturowych, naukowo-badawczych. Debata była okazją do pierwszych deklaracji współpracy

\footnotetext{
${ }^{8}$ M.in. cykl referatów Zbigniewa Cieszkowskiego w latach 2006-2011 na Forach Operatorów Systemów i Odbiorców Energii i Paliw w Warszawie, a także referaty Urszuli Gadomskiej i Zbigniewa Cieszkowskiego na Energetycznym Forum Samorządów i Zakładu Energetycznego Warszawa - Teren SA oraz seminarium Ogólnokrajowego Stowarzyszenia „Poszanowanie Energii i Środowiska” SAPE-Polska w 2007 r.

${ }^{9}$ Referat Urszuli Gadomskiej nt. możliwości wykorzystania odnawialnych źródeł energii w województwie mazowieckim na Festiwalu Nauki i Sztuki w Siedlcach w 2008 r.
} 
pomiędzy samorządami: województwa i miasta oraz Uniwersytetem $\mathbf{w}$ celu realizacji zaproponowanych działań. Ze względu na to, że uczelnia może odegrać szczególnie ważną rolę $\mathrm{w}$ rozwoju rolnictwa $\mathrm{i}$ przemysłu rolno-spożywczego $\mathrm{w}$ subregionie siedleckim, podjęto m.in. decyzję o utworzeniu klastra spożywczego, którego ideę przedstawiono w opracowaniu MBPR (przedmiotowy klaser został powołany w 2015 r.).

Spotkania na temat koncepcji zagospodarowania przestrzennego miejskiego obszaru funkcjonalnego Siedlec odbyły się w grudniu 2015 r. w Urzędzie Miasta Siedlce (fot. 4) oraz w styczniu 2016 r. w Urzędzie Gminy Siedlce. Dyskusja dotyczyła wzmocnienia możliwości rozwojowych przedmiotowego obszaru, obejmującego miasto i otaczającą go gminę Siedlce, a także całego powiatu siedleckiego, głównie poprzez:

- realizację kluczowych inwestycji drogowych (w tym przede wszystkim budowę autostrady A2) i inwestycji elektroenergetycznych w systemie najwyższych napięć;

- prowadzenie skoordynowanej polityki przestrzennej samorządów lokalnych, zwłaszcza $\mathrm{w}$ zakresie planowania terenów produkcyjno-usługowych $\mathrm{w}$ otoczeniu przyszłej autostrady, która będzie znacząco oddziaływała na rozwój przedmiotowego obszaru funkcjonalnego oraz sąsiadujących z nim gmin;

- prowadzenia aktywnej współpracy wszystkich samorządów lokalnych na obszarze

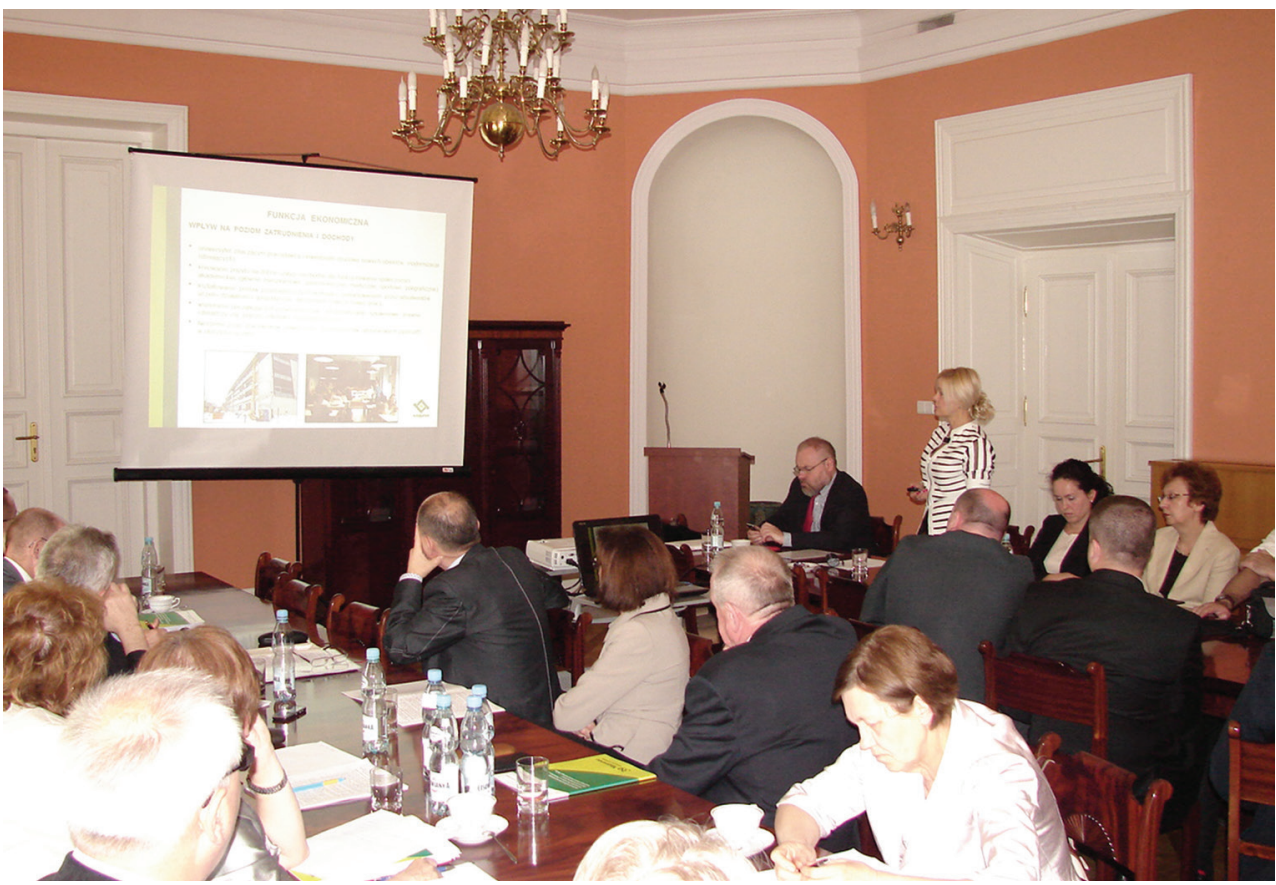

Fot. 3. Debata nt. roli Uniwersytetu Przyrodniczo-Humanistycznego w rozwoju Siedlec i subregionu siedleckiego, UPH w Siedlcach, 5 czerwca 2014 r.

Źródło: materiały archiwalne MBPR 


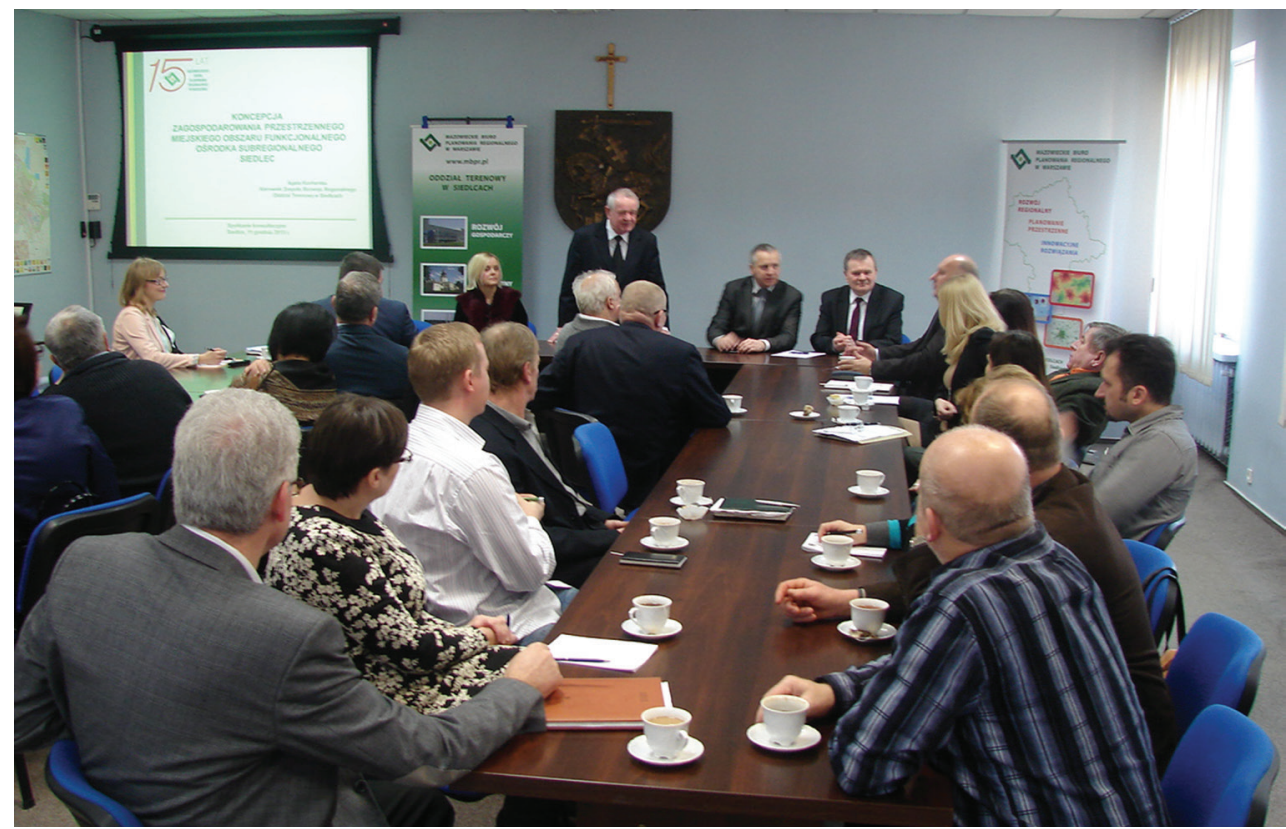

Fot. 4. Spotkanie konsultacyjne ws. koncepcji zagospodarowania przestrzennego miejskiego obszaru funkcjonalnego Siedlec, Urząd Miasta Siedlce, 11 grudnia 2015 r.

Źródło: materiały archiwalne MBPR

powiatu w celu budowania konkurencyjności i prestiżu obszaru funkcjonalnego Siedlec oraz wspólnego zabiegania o środki finan-sowe na inwestycje w subregionie.

Ustalenia $\mathrm{z}$ ww. debat nad rozwojem Siedlec i subregionu siedleckiego miały wpływ na rozpoczęty $w$ tym czasie proces tworzenia wspólnego zintegrowanego planu inwestycyjnego.

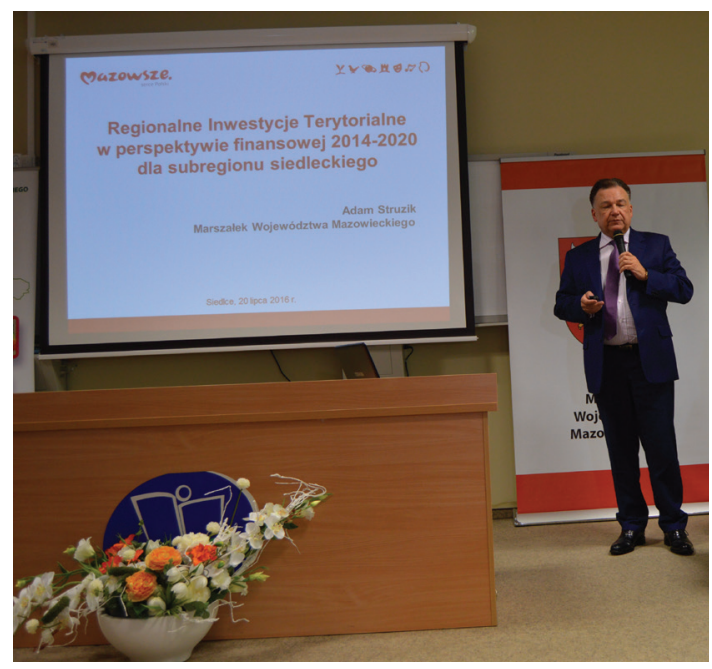

Fot. 5. Konferencja nt. Regionalnych Inwestycji

Terytorialnych dla subregionu siedleckiego, Mazowieckie Samorządowe Centrum Doskonalenia Nauczycieli w Siedlcach, 20 lipca 2016 r. Źródło: materiały archiwalne MBPR 
Plan inwestycyjny dla subregionu siedleckiego w ramach Regionalnych Inwestycji Terytorialnych (RIT)

Miasto Siedlce jest liderem działań w subregionie siedleckim, położonym w zasięgu problemowych obszarów strategicznej interwencji w województwie mazowieckim, dla których w ramach RPOWM 2014-2020 został utworzony mechanizm finansowy RIT (przeznaczony ponadto dla subregionów: ciecha-nowskiego, ostrołęckiego, płockiego i radomskiego). W wyniku umowy partnerskiej pomiędzy Siedlcami i powiatami subregionu siedleckiego został przygotowany plan inwestycyjny o łącznej wartości ponad $400 \mathrm{mln}$ zł, zawierający dwie wiązki spójnych projektów w zakresie: rozwoju infrastruktury transportowej i jej powiązania z transeuropejską siecią transportową (projekt główny obejmuje rozbudowę infrastruktury komunikacyjnej w sąsiedztwie stacji kolejowej w Siedlcach) oraz uzupełnienia infrastruktury społecznej, w szczególności służby zdrowia (projektem głównym jest wyposażenie Siedleckiego Ośrodka Onkologii).

Pracownicy MBPR, w tym Oddziału Terenowego w Siedlcach, wspierali merytorycznie i organizacyjnie proces tworzenia przedmiotowego planu inwestycyjnego poprzez: konsultacje, udział w spotkaniach roboczych i organizację konferencji w lipcu 2016 r. ${ }^{10}$ (fot. 5), na której została przedstawiona procedura realizacji planu, przyjętego przez Zarząd Województwa Mazowieckiego. Byli także członkami zespołu ds. oceny strategicznej tego dokumentu.

Realizacja zaplanowanych inwestycji rozpoczęła się w 2017 r. i będzie trwała do 2020 r. (na koniec 2018 r. zaawansowanie wynosiło ok. 50 \%).

\section{Podsumowanie}

20 lat działalności Mazowieckiego Biura Planowania Regionalnego skłania do podsumowań. Biuro, powołane do realizacji zadań samorządu województwa mazowieckiego w zakresie polityki rozwoju i zagospodarowania przestrzennego, uczestniczyło w procesie budowania samorządności, współpracy i dobrobytu na Mazowszu (wielkość PKB w stosunku do roku 1999 wzrosła ponad 3-krotnie). W tym czasie Siedlce i subregion siedlecki zmieniły się nie do poznania, w dużej mierze dzięki polityce rozwoju, prowadzonej przez władze województwa mazowieckiego, której realizacja była wspierana m.in. środkami z UE, będącymi w dyspozycji samorządu regionu w ramach RPOWM 2007-2013 i RPOWM 2014-2020. Projekty realizowane w subregionie, uznanym za obszar wymagający wsparcia, otrzymały preferencje w konkursach o ich dofinansowanie z ww. programów.

Bardzo ważnym aspektem polityki rozwoju województwa jest także wspieranie współpracy samorządów różnych poziomów w realizacji zadań o znaczeniu ponadlokalnym. Największymi efektami współdziałania jednostek samorządu województwa, w tym MBPR, z samorządami lokalnymi w subregionie siedleckim są inwestycje w ramach RIT, których znaczna część została zrealizowana w 2018 r., a całość zostanie zakończona w 2020 r.

\footnotetext{
${ }^{10}$ Konferencji przewodniczył Pan Adam Struzik - Marszałek Województwa Mazowieckiego.
} 
MBPR, w ramach swojej działalności na rzecz rozwoju regionu, omówionej $\mathrm{w}$ niniejszym artykule m.in. na przykładzie wybranych zadań Oddziału Terenowego w Siedlcach, sporządzało dokumenty strategiczne, programowe i analityczno-studialne, włączając do współpracy wielu interesariuszy, propagowało działalność samorządu województwa na rzecz rozwoju regionu, miało znaczący udział w nawiązaniu współpracy samorządów lokalnych. Biuro uczestniczyło także w przygotowaniu merytorycznym nowych pracowników Urzędu Marszałkowskiego Województwa Mazowieckiego (w ramach odbywanej przez nich służby przygotowawczej), prowadząc wykłady na temat uwarunkowań i kierunków rozwoju regionu ${ }^{11}$.

Na zakończenie chciałabym zwrócić uwagę na podane w przypisach nazwiska kilku koleżanek i kolegów z pierwszego zespołu pracowników Oddziału Terenowego w Siedlcach (część z nich odeszła już na zasłużoną emeryturę), którzy byli współautorami opracowań, omówionych $\mathrm{w}$ niniejszym artykule i wymienionych $\mathrm{w}$ spisie publikacji, dostępnych na stronie internetowej MBPR.

\section{Słownik skrótów}

MBPPiRR - Mazowieckie Biuro Planowania Przestrzennego i Rozwoju Regionalnego

MBPR - Mazowieckie Biuro Planowania Regionalnego

OSI - obszar strategicznej interwencji

PKB - produkt krajowy brutto

PZPWM - Plan zagospodarowania przestrzennego województwa mazowieckiego

RPOWM 2007-2013 - Regionalny Program Operacyjny Województwa Mazowieckiego 2007-2013

RPOWM 2014-2020 - Regionalny Program Operacyjny Województwa Mazowieckiego na lata 2014-2020

RIT - Regionalne Inwestycje Terytorialne

RP - Rzeczpospolita Polska

SRWM - Strategia rozwoju województwa mazowieckiego

UE - Unia Europejska

UPH - Uniwersytet Przyrodniczo-Humanistyczny w Siedlcach

\section{Dokumenty i akty prawne}

Plan Inwestycyjny dla subregionu siedleckiego objętego OSI problemowym, Uchwała nr 1102/166/16 Zarządu Województwa Mazowieckiego z dnia 12 lipca 2016 r. z późniejszymi zmianami.

Plan zagospodarowania przestrzennego województwa mazowieckiego, Uchwała nr 65/2004 Sejmiku Województwa Mazowieckiego z dnia 7 czerwca 2004 r.

Plan zagospodarowania przestrzennego województwa mazowieckiego, Uchwała nr 180/14 Sejmiku Województwa Mazowieckiego z dnia 7 lipca 2014 r.

\footnotetext{
${ }^{11}$ Wykłady w latach 2008-2016 przygotowywała i prowadziła Urszula Gadomska.
} 
Plan zagospodarowania przestrzennego województwa mazowieckiego, Uchwała nr 22/18 Sejmiku Województwa Mazowieckiego z dnia 19 grudnia 2018 r.

Regionalny Program Operacyjny Województwa Mazowieckiego 2007-2013, zatwierdzony przez Komisję Europejską w dniu 10 października 2007 r. oraz zmieniony decyzją z dnia 21 grudnia $2011 \mathrm{r}$.

Regionalny Program Operacyjny Województwa Mazowieckiego na lata 2014-2020, zatwierdzony przez Komisję Europejską w dniu 12 lutego 2015 r.

Strategia rozwoju województwa mazowieckiego, Uchwała $\mathrm{nr}$ 3/01 Sejmiku Województwa Mazowieckiego z dnia 31 stycznia 2001 r.

Strategia Rozwoju Województwa Mazowieckiego do roku 2020 (aktualizacja), Uchwała nr 78/06 Sejmiku Województwa Mazowieckiego z dnia 29 maja 2006 r.

Strategia Rozwoju Województwa Mazowieckiego do roku 2030 Innowacyjne Mazowsze, Uchwała nr 158/13 Sejmiku Województwa Mazowieckiego z dnia 28 października 2013 r.

Studium Planu Zagospodarowania Przestrzennego Obszaru Metropolitalnego Warszawy, 2010, Mazowieckie Biuro Planowania Regionalnego, Warszawa.

\section{Spis publikacji pracowników MBPR OT Siedlce}

Bochenek M., Godlewski G. (red. nauk.), 2006, Walory turystyczne Euroregionu Bug jako czynnik aktywizacji gospodarczej i integracji społeczno-kulturowej w zjednoczonej Europie, Akademia Wychowania Fizycznego Józefa Piłsudskiego w Warszawie, Zamiejscowy Wydział Wychowania Fizycznego w Białej Podlaskiej, Biała Podlaska.

Cieszkowski Z., Polak E., Girczuk J., 2015, Rozwój energetyki opartej na źródłach odnawialnych $w$ województwie mazowieckim - stan i wyzwania, MAZOWSZE Analizy i Studia, 3, 44, Mazowieckie Biuro Planowania Regionalnego, Warszawa.

Dymna B., Dombrowski A., Olszewska A, 2008, Koncepcja szlaków turystyczno-kulturowych. Pasmo Bugu i Liwca, MAZOWSZE Analizy i Studia, 2, 17, Mazowieckie Biuro Planowania Regionalnego, Warszawa.

Dymna B., Dombrowski A., Olszewska A., 2007, Koncepcja szlaków turystyczno-kulturowych Pasmo Wilgi, MAZOWSZE Analizy i Studia, 3, 11, Mazowieckie Biuro Planowania Regionalnego, Warszawa.

Dymna B., Olszewska A., Aftanasiuk M., 2011, Analiza działalności gmin położonych w pasmach turystyczno-kulturowych województwa mazowieckiego na rzecz rozwoju turystyki, MAZOWSZE Analizy i Studia, 2, 27, Mazowieckie Biuro Planowania Regionalnego, Warszawa.

Gadomska U. (red.), Cieszkowski Z., Gochnio B. i in., 2017, Analiza planowanych energetycznych sieci przesyłowych w województwie mazowieckim, Mazowieckie Biuro Planowania Regionalnego, Warszawa (materiał niepublikowany). 
Gadomska U. (red.), Dymna B., Gurbała M. i in., 2015, Koncepcje sieciowych produktów turystycznych w subregionach województwa mazowieckiego, MAZOWSZE Analizy i Studia, 7, 48, Mazowieckie Biuro Planowania Regionalnego, Warszawa.

Gadomska U. i in., 2006, Założenia programu działań w Obszarze Problemowym Nadbużańskim, MAZOWSZE Analizy i Studia, 7, Mazowieckie Biuro Planowania Przestrzennego i Rozwoju Regionalnego, Warszawa.

Gadomska U. (red.), Kucharska A. (red.), Borkowska A., Cieszkowski Z. i in., 2016, Koncepcja zagospodarowania przestrzennego Miejskiego Obszaru Funkcjonalnego Ośrodka Subregionalnego Siedlce, Mazowieckie Biuro Planowania Regionalnego, Warszawa (materiał niepublikowany).

Gadomska U., Cieszkowski Z., Hołubiec E., 2009, Planowanie i organizacja zaopatrzenia w ciepło, energię elektryczna i paliwa gazowe w gminach województwa mazowieckiego, MAZOWSZE Analizy i Studia, 2, 20, Mazowieckie Biuro Planowania Regionalnego, Warszawa.

Gadomska U., Rogowiec M. i in., 2014, Możliwości wykorzystania potencjału Uniwersytetu Przyrodniczo-Humanistycznego dla wzrostu konkurencyjności miejskiego obszaru funkcjonalnego Siedlec, MAZOWSZE Analizy i Studia, 2, 39, Mazowieckie Biuro Planowania Regionalnego, Warszawa.

Mazur K. i in. 2012, Delimitacja obszarów problemowych polityki regionalnej w województwie mazowieckim, MAZOWSZE Analizy i Studia, 4, 35, Mazowieckie Biuro Planowania Regionalnego, Warszawa.

Mazur K., Kierzkowska M., Cieszkowski Z. i in. 2012, Analiza zróżnicowań rozwoju społecznogospodarczego istniejacych i postulowanych podregionówwojewództwa mazowieckiego, MAZOWSZE Analizy i Studia, 1, 32, Mazowieckie Biuro Planowania Regionalnego, Warszawa.

Rogowiec M., 2011, Polityka przestrzenna gmin subregionu siedleckiego w świetle analizy studiów uwarunkowań i kierunków zagospodarowania przestrzennego gmin, MAZOWSZE Analizy i Studia, 1, 26, Mazowieckie Biuro Planowania Regionalnego, Warszawa.

Żabka M., Kowalski R. (red. nauk.), 2007, Przyroda a turystyka we wschodniej Polsce, Wydawnictwo Akademii Podlaskiej, Siedlce.

\section{Strona internetowa}

www.mbpr.pl 


\section{The Mazovian Office for Regional Planning's contribution to the development of Mazovia - results in the Siedlce subregion}

\section{ABSTRACT}

The article presents selected tasks, realized by the Mazovian Office for Regional Planning, which have had a significant impact on development of the Siedlce subregion.

For 20 years, the Office has been fulfilling the duties of the Regional Government of Mazovia in the area of regional and spatial development policy. The Office prepared broadly publicized strategic documents and analytical studies, which allow for thr specifics of individual parts of Mazovia to be taken into account in the regional development policy, carried out by its authorities. The effects in the region's less developed areas, including the Siedlce subregion, included preferences in yhe co-financing projects with European Union funds within subsequent editions of the Regional Operational Program of the Mazovia Region (RPOWM).

Another key aspect of the region's development policy is supporting cooperation between local governments of various levels in the implementation of tasks of supralocal importance. In recent years, as a result of the cooperation of the regional government's units, including the Mazovian Office for Regional Planning, with local governments, integrated investment plans have been prepared in several areas of Mazovia, including the Siedlce subregion. Their implementation is co-financed from the RPOWM 2014-2020 within a dedicated instrument called Regional Territorial Investments.

Key words: regional development policy, Regional Government Mazovia, city of Siedlce, Siedlce subregion

Urszula Gadomska, absolwentka Politechniki Warszawskiej, od 2007 r. dyrektor Oddziału Terenowego MBPR w Siedlcach, współautorka dokumentów planistycznych i strategicznych oraz opracowań analityczno-studialnych dla województw: siedleckiego i mazowieckiego, w latach 2008-2016 prowadziła szkolenia pracowników Urzędu Marszałkowskiego Województwa Mazowieckiego w ramach służby przygotowawczej, kontakt:Mazowieckie Biuro Planowania Regionalnego w Warszawie, Oddział Terenowy w Siedlcach, ul. Pułaskiego 19/21, 08-110 Siedlce, e-mail: ugadomska@mbpr.pl

Urszula Gadomska, a graduate of the Warsaw University of Technology, since 2007 - director of the Branch Office of the MBPR in Siedlce, co-author of planning and strategic documents as well as analytical studies for the Siedleckie and Mazovia regions; in 20082016 she trained employees of the as part of the preparatory service, contact: Mazovian Office for Regional Planning in Warsaw, Branch Office in Siedlce, ul. Pułaskiego 19/21, 08-110 Siedlce, e-mail: ugadomska@mbpr.pl 